\title{
PROFESSIONAL CONFERENCES
}

The thirty-sixth annual session of the Institute of World Affairs, sponsored by the University of Southern California in co-operation with the colleges and universities of the Pacific area, was held at the Huntington-Sheraton Hotel, Pasadena, California, December 6-9, 1959. The Institute of World Affairs is the oldest organization of this kind in the United States. This year's session was under the directorship of James $T$. Watkins, IV, professor of political science, Stanford University. The overall theme of the conference was "This New Age of Discovery." Participants included: The Very Reverend Leonidas C. Contos, Dean, Saint Sophia Cathedral; General Lauris Norstad, USAF, Supreme Allied Commander, Europe; Charles F. Horne, Vice President, Convair; T. Kejth Glennan, The National Aeronautics and Space Administration; Colonel George A. Lincoln, USA, Head, Department of Social Sciences, United States Military Academy; Admiral Arleigh Burke, USN, Chief of Naval Operations; Joseph Caplan, University of California at Los Angeles; Thomas E. Murray, Consultant to the Joint Congressional Committee on Atomic Energy. The Institute's Executive Committee includes Charles E. Martin, University of Washington, J. William Robinson, Whittier College, and Graham H. Stuart, Emeritus, Stanford University. Paul E. Hadley, of the University of Southern California is executive secretary of the Institute and Chancellor Rufus B. von Kleinsmid, of the University of Southern California, is its chancellor.

A conference on the Research Function of University Bureaus and Institutes for GovernmentRelated Research was held August 17-28 at the Bureau of Public Administration, University of California, Berkeley. The Conference was sponsored by Gilbert Y. Steiner, director, the institute of government and public affairs, University of Illinois, York Willbern, director, bureau of gov- ernment research, Indiana University, and Dwight Waldo, director, bureau of public administration, University of California, Berkeley; and was supported by a grant to the sponsors from the Ford Foundation. Participants, in addition to the sponsors, included the following: Charles R. Adrian, Ethan P. Allen, Franklin L. Burdette, Winston W. Crouch, Rowland Egger, George A. Graham, Morton Grodzing, Robert Highsaw, V. O. Key, John W. Lederle, Norton E. Long, Harvey C. Mansfield, Peter H. Odegard, Vicent Ostrom, Frank Pinner, Wallace S. Sayre.

Papers were presented on the following subjects: "Research in Politics"; "Bureau Research and Community Decisions: Some Points of Intercept"; "Public Policy Studies: An Approach to Government Research"; "Comparative Studies"; "Research in Public Administration"; "Research in Metropolitan Affairs"; and "Methods in Social and Political Research." These papers, plus comment thereon, and a summary statement by the conferees will be published in 1960 and will be available from the sponsoring committee.

A new organization, interdisciplinary in nature, called the International Studies Association, has been organized, dedicated to the better teaching, research, and understanding of international relations. The first annual conference was held at the University of California (Berkeley) in April. The program included papers on "A New International Studies Association: Purposes, Problems, and Proposed Organization"; "The Changing Nature of International Relations"; "I There a Discipline of International Relations?" "The Foreign Policy of President DeGaulle." Speakers included Richard C. Snyder of Northwestern, Graham Stuart of Stanford and $M$. Robert Luc, Consul General of France. S. Grover Rich, Jr. of the University of Utah is the general chairman of the new organization.

\section{OTHER ACTIVITIES}

A fourth edition of the biographical Directory of members of The American Political Science Association will be under the editorial direction of Franklin L. Burdette, professor and director of the Bureau of Governmental Research, University of Maryland, College Park. A copy of the Directory will be mailed to each member of the Association upon publication in 1961. The editor asks prompt return of the biographical questionnaire recently sent to each member. Professional biographies of new members joining the Association by the summer of 1960 will be included. 
The Maxwell Graduate School of Syracuse University in cooperation with the Danforth Foundation, will present the second faculty seminar dealing with problems of metropolitan areas during the period August 28th-September 7th. This ten-day seminar will focus on identification of substantive problems of urban regions and on the research methods available for the analysis of those problems. The 1959 seminar was considered very successful as an interdisciplinary approach to the complexity of the metropolis, and this year's plan is built upon that experience.

Section K-Social and Economic Sciences-of the American Association for The Advancement of Science will hold sessions for contributed papers at the annual meeting of the A.A.A.S. in New York, December 26-31, 1960. Association members interested in presenting a paper at these sessions should forward titles and abstracts not later than September 1 to Donald P. Ray, Secretary of A.A.A.S. Section K, National Institute of Social and Behavioral Science, George Washington University, Washington 6, D. C. Papers should be based on research recently completed by the author. The A.P.S.A. is an affiliate member of the Section on Social and Economic Sciences of the A.A.A.S.

The American Council of Learned Societies annouced in late February that in a national competition it had awarded grants to 61 scholars for research in the humanities and related social sciences. Of these, one went to a political scientist, William S. Livingston of the University of Texas, for a study of the British Liberal Party.

A bureau of government research has been established at the University of Rhode Island. John 0 . Stitely became the director of this new bureau in February, 1960. He will continue as associate professor of social science.

On March 28-30 the department of political science at Berkeley held a conference on the French Fifth Republic, organized around three central themes-the constitutional framework of the Fifth Republic, the Fifth Republic and Europe, and the Fifth Republic and Africa. Papers for the first theme were presented by Andre Mathiot and Henry Ehrmann; for the second by Jacques Rueff, Paul Reuter and Roy Macridis; for the third, by Thomas Hodgkin and Benjamin Rivlin. Public lectures were delivered by PaulMarc Henry of the French Foreign Ministry, on "Future Relations Between French-speaking African States and English-speaking States in Africa"; by Thomas Hodgkin on "The States of French-speaking West Africa and Their Neighbore"; by Henry Ehrmann on "Constitutional
Developments in the French Fifth Republic"; and by Milorad Drachkovitch, Berkeley, on "French-American Views on the Fifth Republic." Other participants in the conference, which was chaired by George Lenczowski, included, from France: Lucien Neuwirth, Deputy from the Loire; General Pierre M. Gallois (retired); and Michel Crozier, Center for Advanced Study in the Behavioral Sciences, Palo Alto; from Mali: Gabriel d'Arboussier, Member of the Federal Assembly; from England: William Pickles, London School of Eccnomics; from the United States: Robert Baum, U. S. State Department; James Coleman, University of California at Los Angeles; William Diebold, Council of Foreign Relations; Val Lorwin, University of Oregon; David McLellan, University of California, Riverside; Robert Neumann, University of California, Los Angeles; Calvin Nichols, World Affairs Council, San Francisco; Lowell Noonan, University of Southern California; Theodore Von Laue, University of California, Riverside; Nicholas Wahl, Harvard University; Gordon Wright, Stanford University; and faculty members at Berkeley in political science, history, law, economics and French.

A new survey of graduate programs in public administration, covering all colleges and universities in the United States which currently offer such programs, is presently under way. Launched in March 1960, the survey is being conducted at the request of the American Society for Public Administration by the Higher Education Division of the U. S. Department of Health, Education, and Welfare. The survey is being carried on by means of mail questionnaire and will cover such areas as objectives, admissions policy, organization of the curriculum, degree requirements, student financial assistance, internships, placement services, faculty, and current and cumulative information concerning enrollments and degrees granted.

Ward Stewart specialist in business and public administration in the Division of Higher Education, is director of the survey, and the project is under the general supervision of Harold A. Haswell, Director of the Programs and Homer D. Babbidge, Jr., Assistant Commissioner for Higher Education. Members of the advisory committee include John D. Millett, Miami University (Ohio); Lloyd M. Short, University of Minnesota; Harlan Cleveland, Maxwell School, Syracuse University; Don K. Price, Jr., Harvard University; Henry Reining, Jr., University of Southern California; Donald C. Stone, University of Pittsburgh; Stephen B. Sweeney, University of Penneylvania; and Don L. Bowen, Associate Director, A.S.P.A. Publication of the report, including both narrative text and individual program descriptions, is planned for late 1960 or early 1961. 
The tentative publication title is Graduate Study in Public Administration.

The department of political science at Emory University, in conjunction with the Communicable Disease Center, put on a Management Seminar for Public Administrators, March 14-18, in which Wallace Sayre, Schuyler D. Hoslett, and Rowland Egger participated.

The Graduate School of Public and International Affairs at the University of Pittsburgh conducted a new type of executive development program during the first two weeks of February. It focused on personal development for effective performance of the participants' executive role. Twenty-four senior officials took part, from federal agencies, the Port of New York Authority, two national research organizations, and one city managership. Nathan D. Grundstein, a member of the School's faculty, was the designer and director of the program. Problems, puzzles, visual aids, and other techniques were used at the start to demonstrate obsolescent and inadequate assumptions, patterns, principles, stereotypes, and emotional factors in executive practice.

The Herman Gerlach James Lecture Series in Municipal Government has been established at Ohio University. The lecture series has been named in honor of Dr. James, a former president of Ohio University; and is made possible by a gift of $\$ 10,000$ from Mrs. George E. Frazer, sister of the late Dr. James. The frst lecture will be presented during the academic year 1960-61.

Henry J. Abraham, associate professor of political science at the University of Pennsylvania, was granted one of twenty $\$ 1000$ awards given by the University of Pennsylvania for excellence in teaching. The awards represent a new policy designed to emphasize and provide recognition for superior teaching accomplishments.

Paul C. Bartholomew, professor of political science at the University of Notre Dame, was a visiting lecturer during the winter quarter at the University College, University of Chicago.

Howard Bavender, doctoral candidate at the University of Texas, was appointed assistant professor of political science at the College of Idaho for the spring semester 1959-60.

Leonard Binder of the University of California at Los Angeles has been granted a one semester sabbatical leave and a special leave of one semester to do research in Egypt on political ideologies. His work will be supported by a grant from the Rockefeller Foundation.
Robert Blum, president of the Asia Foundation, served as lecturer at the University of California, Berkeley, for the 1960 spring term.

Irene Blumenthal, formerly of the University of Oregon, has been appointed acting assistant professor in the department of political science and assistant to the overseas programs, at Stanford University.

Phillips Bradley, who was appointed to the United States Information Service on July 2, 1959, is now Attache of Embassy and Public Affairs Officer, USIS, at Kathmandu, Nepal.

R. Wallace Brewster is visiting lecturer at the Institute for American Universities, affliated with the University of Aix-Marseille, France.

John H. Bunzel, of Stanford University, has been appointed to the advisory committee of the newly formed Constitutional Rights Section of the Attorney General's office in California.

Eugene L. Burdick, associate professor of political science at the University of California, Berkeley, was on leave during the 1959 fall semester.

Ben G. Burnett, associate professor of political science at Whittier College, has been appointed director for the achool year 1960-61 of the Whittier College program in Copenhagen, Denmark.

Paul Camp, adjunct professor, in the school of government and public administration of The American University, on April 10, 1959, accepted a Superior Service Award from the Secretary of Health, Education and Welfare "For meritorious contributions to personnel administration, particularly for vision in anticipating manpower needs and planning to meet them."

George A. Codding, assistant professor of political science at the University of Pennsylvania, went to Switzerland between the fall and spring semesters of the current academic year for an intensive study of the recent election of the Swise Federal Council. The trip was financed by a research grant from the University of Pennsylvania.

Jules Cohn, instructor in political science at Brooklyn College, has received a grant-in-aid for research in practical politics from the Eagleton Foundation.

Cornelius P. Cotter, Stanford University, is serving his second year as special consultant to the chairman of the Republican National Committee. 
Robert A. Scalapino, professor of political science at the University of California, Berkeley, is on sabbatical leave during the 1960 spring semester.

Richard F. Schier of Franklin and Marshall College has been granted leave to accept an appointment as deputy superintendent of public instruction for higher education, Commonwealth of Pennsylvania.

Lincoln Smith of New York University has been appointed a member of the Maine Quoddy Commission.

Loren E. Tesdell, assistant professor, has been granted a leave from Temple University during the spring semester, 1959-60 to undertake an exploratory mission in Jordan for the American Friends Service Committee's Social and Technical Assistance Program. Also, during his tenweek stay in the Near East and after returning home, he will continue his research and writing on the administration of the United States and
United Nations technical assistance programs in Jordan and Iraq.

Eric Voegelin, director of the Institut für Politische Wissenschaflen, University of Munich, will spend the fall semester at the University of Notre Dame, under its distinguished professor program.

George V. Wolfe, professor of political science and chairman of the division of economics, history and political science, the College of Idaho, will be spending his sabbatical leave during the epring and summer of 1960 in Europe and the Middle East.

Shao Chi Yuan, formerly assistant professor of public adminjstration at the University of Southern California, has been appointed visiting assistant professor of political science at Kansas State University.

Harold Zink of Ohio State University is teaching at Victoria University in New Zealand in the spring and summer, 1960.

\section{APPOINTMENTS AND STAFF CHANGES}

Donald Balmer has been named chairman of the political science department, Lewis and Clark College.

John C. Bollens has been promoted to professor at the University of California at Los Angeles.

Zbigniew Brzezinski has accepted a post as associate professor of government at Columbia University, effective July, 1960.

Fred G. Burke, Ohio Wesleyan University, has been appointed an associate professor of political science at the Maxwell School, Syracuse University.

The Rev. Joseph T. Cahill, C.M., has been appointed dean of the college of arts and sciences and also academic vice president of Niagara University.

Lawrence H. Fuchs has been appointed as dean of faculty at Brandeis University after serving as chairman of the department of politics.

Joseph P. Ganley, C. M., has been appointed assistant professor in the department of history and political science at Niagara University.
David T. Cattell has been named associate professor in the department of political science at U.C.L.A.

John Crampton has joined the faculty of Lewis and Clark College as assistant professor.

Joseph P. Farry has joined the political science faculty of Fordham University as an instructor.

William Fleming, chairman of the department of political science at Ripon College, Ripon, Wisconsin has been promoted to the rank of professor of political science.

Edward B. Glick, formerly director of the Commission on International Affairs of the American Jewish Congress is now a senior human factors specialist with System Development Corporation, which is connected with the Rand Corporation.

William M. Goldsmith has been appointed as assistant professor of politics at Brandeis.

Robert E. Goostree has been promoted to the rank of professor of government and public administration at the American University. 